\title{
EDITORIAL VOL 7 N 1
}

Na contracorrente da nova musicologia e das ideias pós modernas, Brandão traz um interessante debate sobre o aclamado livro de Sandroni - Feitiço decente (2001) -, apontado como "referência obrigatória" nos estudos da música brasileira. "A partir de uma postura polemística", Brandão procura aprofundar a discussão sobre o que chama de "certos equívocos metodológicos na forma como Sandroni utiliza conceitos musicais, especialmente rítmicos, presentes na música popular brasileira e de matriz africana", que "deixam transparecer o caráter ideológico por trás de tal postura analítica", alertando que certas "premissas ideológicas de uma certa 'musicologia nova' podem turvar e limitar a visão sobre expressões musicais não hegemônicas".

Em "O pecador - para sagrada comunhão: reconstituição da obra de Florêncio José Ferreira Coutinho" (1750-1819), Emboaba realiza a reconstituição e a edição de um manuscrito pertencente ao acervo de partituras do Museu da Inconfidência (MG), através de uma metodologia exploratória, descrevendo o passo a passo de suas decisões musicológicas; e Correa traz uma análise harmônica e instrumental do Concerto Carioca n. I, de Radamés Gnatalli, para guitarra elétrica e orquestra, ressaltando o compromisso do compositor com a música brasileira.

Como resultado das experiências durante a pandemia, Bonfim, Sulpício, Corvisier e Berg trazem considerações sobre pedagogia e motivação em aulas online. Sonia Albano, nossa convidada desta edição, trata da relação entre a música e o físico e o mental humanos, tendo como base os trabalhos de Maria Cândida Moraes (2003), Storr (2002), Viellard e Bigan (2005), entre outros, na maioria, pesquisadores focados na cognição musical. Em "Adeus, Pirandello...", Marzullo estuda as relações entre a obra de Lucchesi e o opus 133 de Beethoven, buscando linhas comuns entre as duas obras.

Thiesen publica sua comunicação no evento que deu origem ao dossiê, cuja segunda e última parte publicamos nesta edição - "(Re) Discussão Sobre As Grandes Áreas Do Conhecimento: Crítica À Epistemologia Fundamental - Ruminações". Nela, a autora formula questões debatidas naquele seminário do IEA/USP (Instituto de Estudos Avançados da Universidade de São Paulo), em 2018, problematizando alguns aspectos relacionados à Literatura, à Filosofia, à Música e à História. 
dossiê, propriamente dito, que fecha este número, descreve o que aconteceu naqueles três dias memoráveis, sempre sublinhando a importância do Manifesto de Leiden, apresentando ao leitor "as falas de professores e convidados que participaram dos debates sobre os problemas da avaliação do conhecimento por meio de métricas redutivas, da fragmentação do saber em áreas isoladas que não mais conversam entre si e da exclusão de outras formas de expressão científica, além do paper".

Prof. Dr. Marcos Câmara de Castro Editor-gerente 